\title{
OPTIMIZATION OF EDTA ENHANCED SOIL WASHING ON MULTIPLE HEAVY METALS REMOVAL USING RESPONSE SURFACE METHODOLOGY
}

\author{
Liwei HE, Bin LI, Ping NING*, Xiao GONG \\ Faculty of Environmental Science and Engineering, Kunming University of Science and Technology, \\ Kunming 650093, P. R. China
}

Received 11 July 2018; accepted 19 July 2018

\begin{abstract}
This research presents the optimization of soil washing conditions in the removal of multiple heavy metals (Cu$\mathrm{Pb}-\mathrm{Zn}-\mathrm{Cd}$ ) under the using of ethylenediaminetetraacetic acid (EDTA). The optimum combination of washing parameters in a bench-scale soil washing experiments is determined by response surface methodology (RSM). Central composite design is applied after single factor experiment, EDTA concentration, solid-to-liquid ratio and washing time are evaluated variables for the removal processes, and the regression models of HMs are constructed. The results show that, EDTA concentration and solid-to-liquid ratio are significant factors for this process. Subsequently, $50 \%$ of $\mathrm{Cu}$ removal was set as the optimum target to optimize the combined conditions, through the building of multiple quadratic regression models, the optimal condition combination is determined that EDTA concentration is $0.0026 \mathrm{~mol} \cdot \mathrm{L}^{-1}$, solid-to-liquid ratio is $1: 22$, washing time is $3.89 \mathrm{~h}$, the extraction rate of $\mathrm{Pb}, \mathrm{Zn}, \mathrm{Cd}$ is predicted to be $78 \%, 75 \%$ and $71 \%$, respectively.
\end{abstract}

Keywords: soil cleaning technologies, soil washing, multiple heavy metals pollution, response surface methodology.

\section{Introduction}

Soil pollution caused by heavy metals (HMs) has become a widespread global problem for their non-biodegradation and long residence time (Wuana, Okieimen, \& Imborvungu, 2010; Evangelou, Bauer, Ebel, \& Schaeffer, 2007). HMs pollutants in the soil could lead to adverse effects on environment and serious threat to humans (Ferraro, Fabbricino, Hullebusch, Esposito, \& Pirozzi, 2016). Single type of heavy metal has been intensively studied of late years, nevertheless, a number of HMs always co-exist in common types of contamination sites (Arao et al., 2010; Moutsatsou, Gregou, Matsas, \& Protonotarios, 2006). In many parts of the world, soil HMs derives normally from long-term utilization of phosphatic fertilizers, mining and smelt industry, and sewage sludge disposal (Ciccu et al., 2003; Xia et al., 2009; Mandal, Purakayastha, \& Patra, 2014). Multiple Multiple HMs pollution of soils is one of the environmental concerns in recent decades, which led to consequently urgent need of effective remediation technologies.

Various techniques for the removal of HMs from contaminated soils, have been investigated and adopted to reduce the prospective healthy and migration risk. For instance, solidification/stabilization, soil flushing, phytoremediation, microbial remediation and soil washing (Wasay, Barrington, \& Tokunaga, 2013; Dermont, Bergeron, Mercier, \& Richerlaflèche, 2008), among them, ex-situ soil washing has becoming a more and more widely used method due to its simple operation, efficiency, and barely limited by site environment (Daniel, Irene 2006; Tsang \& Lo, 2006; Voglar \& Lestan, 2012). Ex-situ soil washing process bases on the idea of water rinsing to remove pollutants from soil and to transfer them to a concentrated liquid phase (Mao, Jiang, Xiao, \& Yu, 2015). Generally speaking, it includes either a physical separation, or a chemical extraction, although both the physical and the chemical washing often coexist in most cases (Peters, 1999; Di Palma, Ferrantelli, \& Medici, 2005). Many different chemicals like acid solutions, diluted acid solutions containing chloride salts, surfactants, reducing and oxidizing agents, and chelants are of high extraction efficiency for HMs in the soil (Dermont et al., 2008). For the purpose of removing various types of contaminant from soil, chemical-enhanced soil washing has been comprehensively studied in recent years (Lo, Tanboonchuy, Yan, Grisdanurak, \& Liao, 2012; Gao, He, Ling, Hu, \& Liu, 2003; Haapea \& Tuhkanen, 2006).

A variety of factors contribute to the effectiveness of the washing process, including properties of the target

*Corresponding author. E-mail: 1143551103@qq.com 
contaminants, soil texture and extraction solution, among them, the type of washing solution is of critical importance (Mulligan, Yong, \& Gibbs, 2001). Chelating agents are always used to improve remove ability in physicalchemical remediation. Among them, ethylenediaminetetraacetic acid (EDTA) has strong chelating ability for different heavy metals (Sun, Zhao, \& Lombi, 2001; Leštan, Luo, \& Li, 2008; Finzgar, Jez, Voglar, \& Lestan, 2014; Guo et al., 2016), which is cited frequently as an effective agent in the removal of HMs from contaminated soils, thus, EDTA was chosen as the washing solution in this study.

The majority of reported studies of optimization of chemical process parameters involved with the method of changing one variable while maintaining other formulation variables constant, which was not only time-consuming and tedious, but also giving rise to the cost (Lo et al., 2012). Comparatively speaking, design of experiments (DoE) approach has become a useful tool in quality controlling for both single-factor and multi-factor experiment (Lionberger, S. L. Lee, L. Lee, Raw, \& Yu, 2008). Takes full use of DoE in predictive model construction of the critical response variables could facilitate identification of all potential independent variables and their simultaneous systematic and rapid evaluation (Poudel et al., 2012). Response surface methodology (RSM) is a collection of statistical and mathematical DoE techniques for modelling and analysis responses influenced by several variables, which are more reliable than unplanned experiments (Dean \& Voss, 2010). Numerous studies have described RSM in metabolites producing from microorganisms (Elnaggar, Elshweihy, \& Elewasy, 2016; Hwang et al., 2012), culture conditions determination in extracellular metabolites producing (Shen et al., 2014; Moradpour, Ghasemian, Mohkam, \& Ghasemi, 2012), and drug producing (Gupta et al., 2016), whereas, it was rarely used in optimization of chemical processes. Therefore, the purpose of this study was using central composite design (CCD) of RSM to optimize the conditions for the removal of $\mathrm{Cu}$, $\mathrm{Pb}, \mathrm{Zn}$ and $\mathrm{Cd}$ from the contaminated soils in the process of soil washing with EDTA. The relationship between the response (remove rate) and input variables (EDTA concentration, washing time, solid-to-liquid ratio) were fit and explored. A batch of experiments was designed, and the removal effect was determined by the remove rate of the total concentration of HMs in the soil.

\section{Materials and methods}

\subsection{Soil sampling and preparation}

Surface soils $(0-20 \mathrm{~cm})$ were collected from 5 sample points in paddy field in southwest of China. Soil samples were blended well after taking to the laboratory, then airdried under room temperature. Coarse debris and visible plant materials were eliminated by a $1 \mathrm{~mm}$ nylon sieve. The soil $\mathrm{pH}$ was measured in a 1:2.5 $(w / v)$ ratio of soil and $0.01 \mathrm{M} \mathrm{CaCl}_{2}$ water solution suspensions. The soil organic matter was determined by potassium bichromate titrimetric method described in GB 9834-88:1988. Method for determination of soil organic matter. The cation exchange capacity was analyzed using the ammonium acetate method, and the soil particle distribution was measured by laser granulometry (Beckman Coulter, LS230). The physicochemical properties of soil show that soil $\mathrm{pH}$ value was 6.5 , organic matter was $20.3 \mathrm{~g} \cdot \mathrm{kg}^{-1}$, cation exchange capacity was $17.5 \mathrm{cmol} \cdot \mathrm{kg}^{-1}$, moisture content was $6.4 \%$, sand percentage is $10.3 \%$, clay percentage is $21.4 \%$, silt percentage is $38.3 \%$.

Total metal concentrations in paddy field were: $\mathrm{Cu} 122 \mathrm{mg} \cdot \mathrm{kg}^{-1}, \mathrm{Zn} 195 \mathrm{mg} \cdot \mathrm{kg}^{-1}, \mathrm{~Pb} 41 \mathrm{mg} \cdot \mathrm{kg}^{-1}$, Cd $0.01 \mathrm{mg} \cdot \mathrm{kg}^{-1}$, suggesting that only $\mathrm{Cu}$ pollution existed in the applied soil according to the Chinese National Standard of the Environmental quality standard for soils (GB 15618-1995), $\mathrm{pH}$ below 6.5 for paddy soil, the standard value is $\mathrm{Cu} 50 \mathrm{mg} \cdot \mathrm{kg}^{-1}, \mathrm{Zn} 200 \mathrm{mg} \cdot \mathrm{kg}^{-1}, \mathrm{~Pb}$ $250 \mathrm{mg} \cdot \mathrm{kg}^{-1}$, Cd $0.30 \mathrm{mg} \cdot \mathrm{kg}^{-1}$, respectively.

Since sampling of natural severely polluted agricultural soil with multiple heavy metals is difficult, spiked soil by artificially contamination with heavy metal solution were frequently adopted in the lab (Kulikowska, Gusiatin, Bułkowska, \& Kierklo, 2015; Kang \& So, 2016; Cameselle \& Pena, 2016). In order to meet the study objective of exploring the removal efficiency of EDTA enhanced soil washing in multiple heavy metals contaminated soil, $\mathrm{Cd}\left(\mathrm{NO}_{3}\right)_{2}, \mathrm{Cu}\left(\mathrm{NO}_{3}\right)_{2}, \mathrm{Zn}\left(\mathrm{NO}_{3}\right)_{2}, \mathrm{~Pb}\left(\mathrm{NO}_{3}\right)_{2}$ solutions were added to the pretreated soil samples to simulate contaminated soils. Spiked soil samples were left at room temperature for one month, and distilled water were added at regular intervals to keep field capacity at about $10 \%$ level.

For the purpose of keeping the soil $\mathrm{pH}$ at the value of $6.0, \mathrm{HCl}$ solution of $0.01 \mathrm{~mol} \cdot \mathrm{L}^{-1}$ was used to adjust $\mathrm{pH}$ value from 6.5 to $6.0, \mathrm{NaOH}$ solution of $0.01 \mathrm{~mol} \cdot \mathrm{L}^{-1}$ was used to neutralize the excessive amount of $\mathrm{HCl}$ during the experimental operation. Afterwards, simulated soil samples were kept at room temperature then naturally air-dried. Total metal concentrations in artificially contaminated soils were: $\mathrm{Cu} 668 \mathrm{mg} \cdot \mathrm{kg}^{-1}, \mathrm{Zn} 383 \mathrm{mg} \cdot \mathrm{kg}^{-1}$, $\mathrm{Pb} 397 \mathrm{mg} \cdot \mathrm{kg}^{-1}, \mathrm{Cd} 31 \mathrm{mg} \cdot \mathrm{kg}^{-1}$.

\subsection{Chemical agents}

EDTA solutions of $0.001,0.002,0.003,0.005,0.010$ and $0.015 \mathrm{~mol} \cdot \mathrm{L}^{-1}$ were prepared with $0.01 \mathrm{~mol} \cdot \mathrm{L}^{-1} \mathrm{NaNO}_{3}$ solution to control ionic strength, $0.01 \mathrm{~mol} \cdot \mathrm{L}^{-1} \mathrm{HCl}$ and $0.01 \mathrm{~mol} \cdot \mathrm{L}^{-1} \mathrm{NaOH}$ solution were used to adjust $\mathrm{pH}$. Chemical agents used in the experiment were of analytical grade purity.

\subsection{Statistical analysis}

RSM is divided into two categories, Box-Behnken design (BBD) and CCD. The latter approach was selected to evaluate the interaction of different factors and their effects on EDTA washing. CCD requires less number of experiments, which is a valuable tool to assess the optimization responses shaped under the influence of multiple 

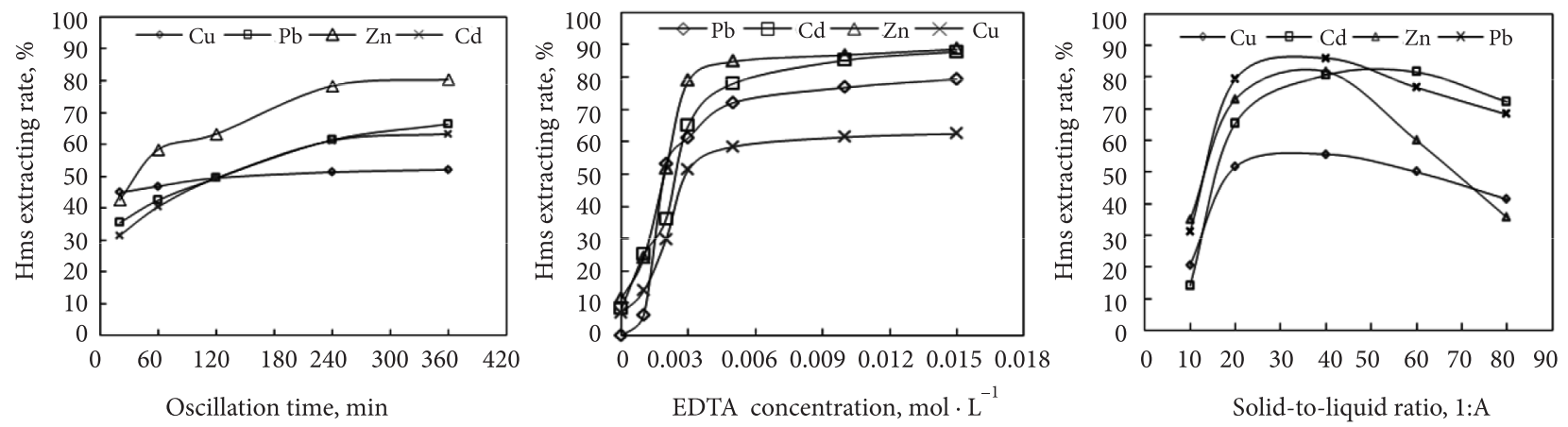

Figure 1. Effect of single process parameter on EDTA enhanced soil washing

independent factors and their degree of interaction (Tanyildizi, 2011; Sugashini \& Begum, 2013). It could probe the optimum level of each factor by building a mathematical model and generating three-dimensional (3D) response surface images, which could give better prediction and directly overview for the parameter optimization (Madeira, Ribeiro, Turk, \& Cabral, 2010).

The one-variable-at-a-time method was used as the first step to determine the equilibrium values, which were chosen as center points used in the next step of experimental design. Basing on synthesized analysis of four types of HMs in this work, highest extracting rate was set as the optimization target, CCD experiments were implied to obtain their optimum combination.

In our study, the responses, which were the dependent variables, were the extraction rates of $\mathrm{Cu}\left(Y_{1}\right), \mathrm{Pb}$ $\left(Y_{2}\right)$, Zn $\left(Y_{3}\right)$ and $\mathrm{Cd}\left(Y_{4}\right)$. EDTA concentration $(A)$, solid-to-liquid ratio $(B)$, and oscillating time $(C)$ were selected as independent variables. The CCD experiments of three variables, each had 5 levels $( \pm 1$ for the factorial points, 0 for the center point, and $\pm \alpha$ for the axial points), which has allowed estimation of a full quadratic model with the general description: $N=2^{k-p}+2 k+C_{0}$, where $N$ is the number of experiments, $k$ is the number of independent variables $(k=3), p$ the fractionalization number (in a full design, $p=0$ ) and $C_{0}$ is the number of central points $\left(C_{0}=6\right)$, required for curvature estimation (Barker, 1985).

The design and result analysis of CCD experiment were performed by using Design Expert 8.0.6.1 (Stat-Ease, Inc Minneapolis, MNUSA). The lowest and the highest levels of variables were given in Table 1.

\section{Results and discussion}

\subsection{Results of EDTA washing experiment}

The washing processes were carried out with $1.0 \mathrm{~g}$ soil samples mixed with EDTA solution in $50 \mathrm{~mL}$ centrifuge tubes, the suspensions were oscillated at $20{ }^{\circ} \mathrm{C}$ with $\mathrm{pH}$ value fixed at 6 . After oscillating, the samples were centrifuged at $4000 \mathrm{r} / \mathrm{min}$ for $10 \mathrm{~min}$ and filtered by $0.45 \mu \mathrm{m}$ micropore filter, supernatants were separated to measure metal concentrations by inductively coupled plasma
Table 1. Uncoded and coded levels of the independent variables

\begin{tabular}{|l|l|c|c|c|c|c|}
\hline \multirow{2}{*}{$\begin{array}{l}\text { Independent } \\
\text { variables }\end{array}$} & \multicolumn{5}{|c|}{ Coded levels } \\
\cline { 2 - 6 } & -2 & -1 & 0 & 1 & 2 \\
\hline A & $\begin{array}{l}\text { EDTA } \\
\text { concentration } \\
/ \text { mol-mL }^{-1}\end{array}$ & 0 & 0.001 & 0.003 & 0.005 & 0.006 \\
\hline B & $\begin{array}{l}\text { Solid-to-liquid } \\
\text { ratio }\end{array}$ & $1: 5$ & $1: 10$ & $1: 20$ & $1: 30$ & $1: 35$ \\
\hline C & $\begin{array}{l}\text { Washing } \\
\text { time/h }\end{array}$ & 1 & 2 & 4 & 6 & 7 \\
\hline
\end{tabular}

mass spectroscopy with experiment detection limits at $0.01 \mathrm{mg} \cdot \mathrm{L}^{-1}$.

Washing time, EDTA concentration, and solid-toliquid ratio were probed to assess their effects on EDTA enhanced soil washing. Batches of experiments were conducted to optimize the value for each parameter for further experiments. The time used in oscillation was set from 10 min to 480 mins $(10,20,40,60,120,240,360$, 480 mins) with $50 \mathrm{~mL} 3 \mathrm{mmol} \cdot \mathrm{L}^{-1}$ EDTA solution added to $1 \mathrm{~g}$ soil samples to optimize the washing time. The effect of EDTA concentration was studied by adding $50 \mathrm{~mL}$ $0.001 \mathrm{~mol} \cdot \mathrm{L}^{-1}$ to $0.015 \mathrm{~mol} \cdot \mathrm{L}^{-1} \mathrm{EDTA}$ solutions $(0.001$, $\left.0.002,0.003,0.005,0.01,0.015 \mathrm{~mol} \cdot \mathrm{L}^{-1}\right)$ in soil samples with 4 hours oscillation. Solid-to-liquid ratio, ranged from 1:20 to $1: 80(\mathrm{w} / \mathrm{v})$ with an interval of 20 , was studied by adding 20, 40, 60 and $80 \mathrm{~mL} 0.003 \mathrm{~mol} \cdot \mathrm{L}^{-1}$ EDTA solution to $1 \mathrm{~g}$ soil sample with 4hours oscillation, respectively. All of the washing disposes were triplicated, and the average of extracting rate was taken as the dependent variable or response.

The results showed that extraction rates of four varieties of $\mathrm{HMs}, \mathrm{Cu}, \mathrm{Pb}, \mathrm{Zn}, \mathrm{Cd}$ were basically of consistent tendency under selected variables. As the values of selected variables increased, the extraction rates inhibited a rapid improvement at first and then gradually remained constant and rose to an equilibrium (Figure 1).

\subsection{Central Composite Design experimental results}

A total of $20\left(2^{3-0}+2 \times 3+6\right)$ combinations (including six replicates of the central point each signed the coded value 0 ) were chosen according to a CCD configuration 
for three independent variables. The results of HMs extraction rate were showed in Table 2.

\subsection{Development of regression model}

Regression models were built, and the analysis of variance (ANOVA) were conducted.

(a) Regression model analysis of extraction rate of $\mathrm{Cu}$.

The second-order polynomial regression equation showing the relationship between the $\mathrm{Cu}$ extraction rate and three test variables is presented in Eq. (1):

$$
\begin{aligned}
& Y_{1}=-71.3301+25.30233 \times A+5.48281 \times B+ \\
& 1.43325 \times C-0.24836 \times A \times C-0.087287 \times A \times \\
& B+0.010889 \times B \times C-1.94315 \times A^{2}-0.084118 \times \\
& B^{2}-0.12339 \times C^{2},
\end{aligned}
$$

where $Y_{1}$ is the extraction rate of $\mathrm{Cu} ; A$ is the concentration of EDTA solution $\left(10^{-3} \mathrm{~mol} \cdot \mathrm{L}^{-1}\right) ; B$ is the ratio of solid-to-liquid; $C$ is the time of oscillation.

The results of analysis of ANOVA for $Y_{1}$ were showed in Table 3 . The model was statistically extremely significant at the $95 \%$ confidence level $(P<0.0001)$. Lack of fit test was determined by the ratio of lack of fit error to pure error $\left(\mathrm{MS}_{\mathrm{LF}} / \mathrm{MS}_{\mathrm{PE}}\right)$. $P$ value of lack of fit was not significant, which meant that there was no evidence of lack of fit. In general, the $R^{2}$ value was between 0 and 1 , the closer the $R^{2}$ approximates to 1 , the stronger is the model and the better it predicts the response (Gangadharan, Sivaramakrishnan, Nampoothiri, Sukumaran, \& Pandey, 2008). The coefficient of determination $\left(R^{2}\right)$ was calculated to be 0.9816 , which means that the model explains
Table 3. ANOVA for the reduced quadratic model (Eq. 1)

\begin{tabular}{|c|c|c|c|c|}
\hline Source & df & SS & MS & Prob $>$ F \\
\hline Model & 9 & 841 & 120 & $<0.0001$ \\
\hline A & 1 & 3467 & 495 & $<0.0001$ \\
\hline B & 1 & 2508 & 358 & $<0.0001$ \\
\hline C & 1 & 8 & 1.15 & 0.308 \\
\hline AB & 1 & 197 & 28 & 0.0003 \\
\hline AC & 1 & 0.98 & 0.14 & 0.7169 \\
\hline BC & 1 & 0.38 & 0.06 & 0.8207 \\
\hline A2 & 1 & 623 & 89 & $<0.0001$ \\
\hline B2 & 1 & 729 & 104 & $<0.0001$ \\
\hline C2 & 1 & 2.51 & 0.36 & 0.5627 \\
\hline residual & 10 & 7 & & \\
\hline
\end{tabular}

$98.16 \%$ of the values in the experiment. The model for $Y_{1}$ was well fitted.

The relationships between independent and dependent variables can be easily visualized using RSM, where the obtained regression model was used to calculate the response surface for each response variable. The significance of the coefficients represented by $P$ value is a valid parameter in checking the pattern of mutual interactions between variables (Khosravi, Vasheghani, Shojaosadati, \& Yamini, 2004). For $Y_{1}$, two main factors $(A, B)$, one interaction term $(A B)$, and two second order factors $\left(A^{2}, B^{2}\right)$ were significant $(P<0.05)$. It indicated that the extraction rate of $\mathrm{Cu}$ was significantly influenced by EDTA concentration and solid-to-liquid ratio, and there was an obvious interaction between EDTA concentration and solid-to-liquid ratio. The order of factors that affected the extraction

Table 2. Experimental design and results for CCD of response surface methodology

\begin{tabular}{|c|c|c|c|c|c|c|c|c|c|c|c|}
\hline \multirow{2}{*}{ Code } & \multirow{2}{*}{$\mathrm{A}$} & $\mathrm{B}$ & $\mathrm{C}$ & \multicolumn{7}{|c|}{ Extraction rate/\% $(Y)$} \\
\cline { 5 - 12 } & & & & $Y_{1}^{\mathrm{a}}$ & $Y_{1}^{\mathrm{b}}$ & $Y_{2}{ }^{\mathrm{a}}$ & $Y_{2}{ }^{\mathrm{b}}$ & $Y_{3}{ }^{\mathrm{a}}$ & $Y_{3}{ }^{\mathrm{b}}$ & $Y_{4}{ }^{\mathrm{a}}$ & $Y_{4}{ }^{\mathrm{b}}$ \\
\hline 1 & 0 & 20 & 4 & 9.9 & 8.4 & 4.2 & 5.8 & 10.9 & 20.5 & 16.0 & 21.4 \\
\hline 2 & 1 & 30 & 6 & 37.8 & 38.3 & 55.3 & 56.6 & 46.4 & 48.5 & 28.8 & 41.3 \\
\hline 3 & 3 & 20 & 4 & 52.0 & 59.3 & 83.7 & 83.1 & 77.0 & 78.5 & 73.8 & 76.3 \\
\hline 4 & 1 & 10 & 2 & 0.7 & 0.1 & 3.3 & -6.3 & 17.8 & 13.8 & 6.5 & 9.0 \\
\hline 5 & 1 & 10 & 6 & 0.9 & 0.5 & 4.3 & -6.5 & 12.6 & 11.0 & 8.4 & 8.8 \\
\hline 6 & 3 & 20 & 7 & 51.7 & 53.9 & 84.5 & 87.1 & 79.4 & 78.0 & 74.7 & 69.9 \\
\hline 7 & 3 & 20 & 4 & 51.3 & 59.3 & 83.9 & 83.1 & 78.7 & 78.5 & 75.4 & 76.3 \\
\hline 8 & 1 & 30 & 2 & 33.7 & 41.0 & 56.2 & 56.8 & 48.9 & 51.4 & 40.6 & 50.7 \\
\hline 9 & 3 & 20 & 4 & 52.0 & 59.3 & 83.9 & 83.1 & 78.7 & 78.5 & 75.4 & 76.3 \\
\hline 10 & 5 & 10 & 6 & 45.7 & 46.9 & 81.6 & 77.6 & 57.1 & 54.6 & 62.3 & 57.4 \\
\hline 11 & 5 & 30 & 6 & 59.7 & 66.4 & 89.8 & 92.8 & 88.4 & 92.4 & 91.9 & 94.7 \\
\hline 12 & 3 & 20 & 4 & 52.0 & 59.3 & 83.9 & 83.1 & 78.7 & 78.5 & 75.4 & 76.3 \\
\hline 13 & 3 & 35 & 4 & 58.2 & 62.8 & 85.2 & 78.4 & 80.6 & 73.7 & 90.7 & 73.0 \\
\hline 14 & 3 & 20 & 4 & 52.0 & 59.3 & 83.9 & 83.1 & 78.7 & 78.5 & 75.4 & 76.3 \\
\hline 15 & 5 & 10 & 2 & 43.8 & 52.0 & 79.1 & 74.5 & 56.1 & 53.9 & 63.9 & 56.8 \\
\hline 16 & 3 & 5 & 4 & 6.8 & 12.9 & 70.0 & 19.8 & 10.3 & 17.1 & 15.4 & 13.7 \\
\hline 17 & 3 & 20 & 1 & 49.0 & 62.5 & 81.5 & 84.9 & 78.3 & 79.7 & 81.1 & 76.5 \\
\hline 18 & 5 & 30 & 2 & 60.0 & 86.7 & 86.5 & 89.6 & 90.1 & 91.8 & 98.4 & 103.3 \\
\hline 19 & 3 & 20 & 4 & 52.0 & 59.3 & 83.9 & 83.1 & 78.7 & 78.5 & 75.4 & 76.3 \\
\hline 20 & 6 & 20 & 4 & 58.0 & 75.2 & 93.3 & 93.5 & 84.1 & 83.5 & 92.0 & 97.2 \\
\hline
\end{tabular}

Note: ${ }^{\mathrm{a}}$ - actual values of response (dependent variables); ${ }^{\mathrm{b}}$ - predicted values of response (dependent variables). 
a)

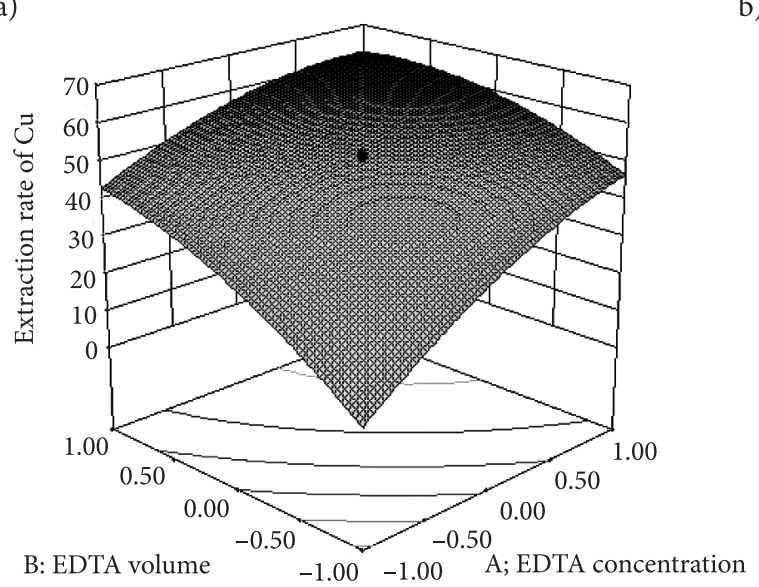

c)

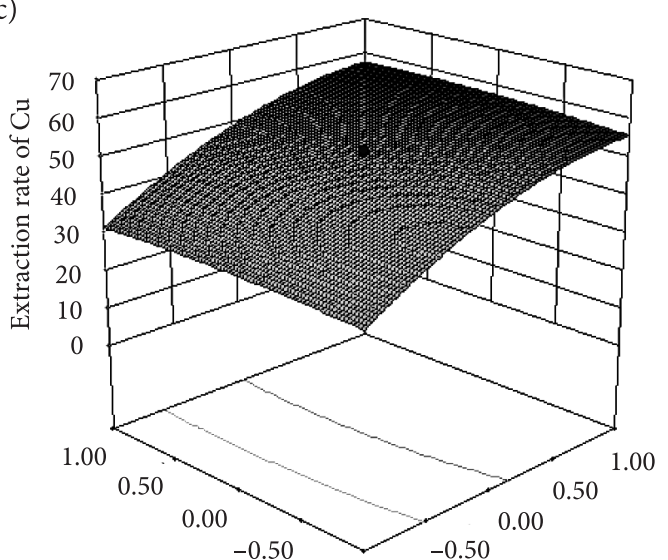

$\begin{array}{llll}C \text {; washing time } & -1.00 & -1.00 \quad \text { B: EDTA volume }\end{array}$

e)

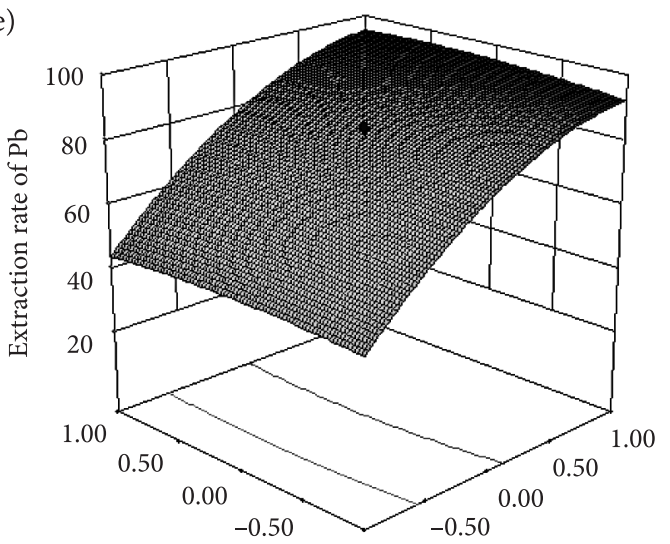

C; washing time $\quad-1.00-1.00 \quad$ A; EDTA concentration

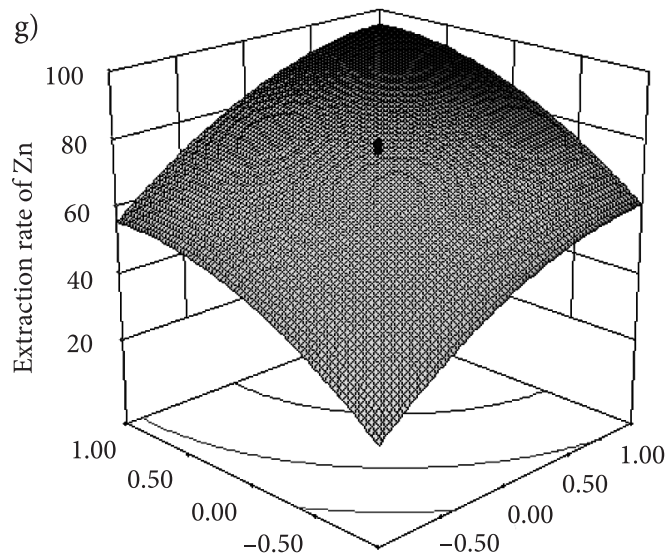

B: EDTA volume $\quad-1.00-1.00 \quad$ A; EDTA concentration

b)

f)

h)

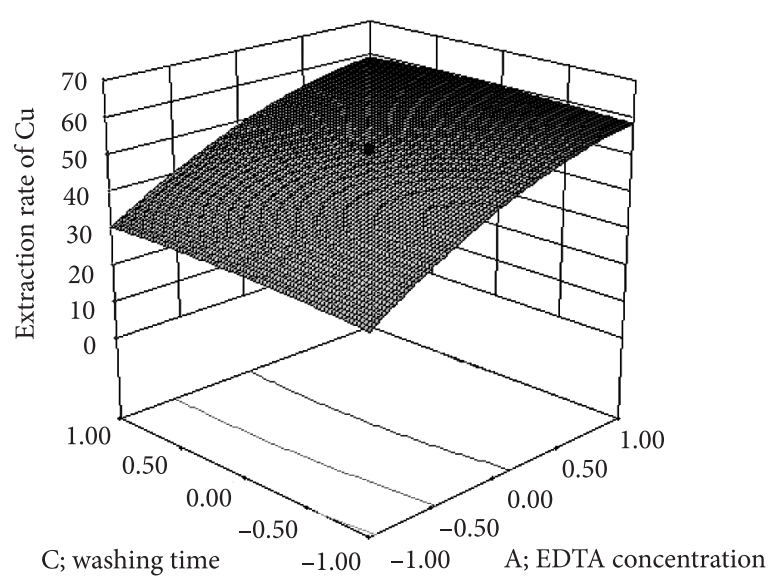

d)
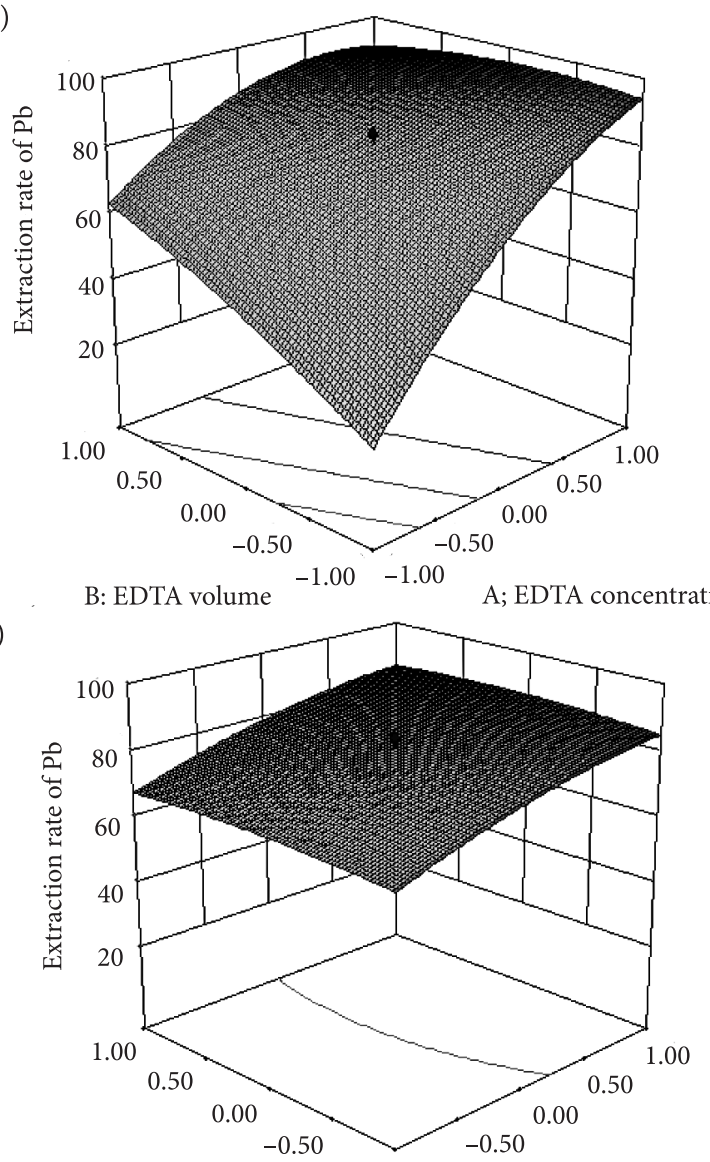

C; washing time $\quad-1.00 \quad-1.00 \quad$ B: EDTA volume

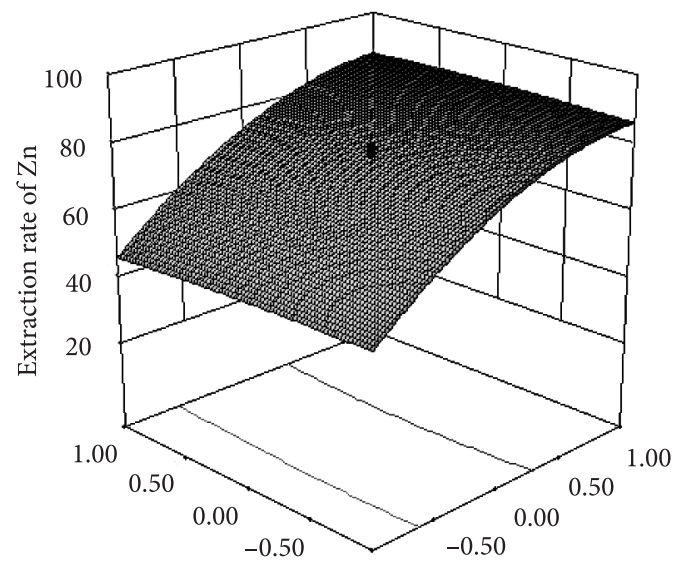

C; washing time $\quad-1.00 \quad-1.00 \quad$ A; EDTA concentration 
i)

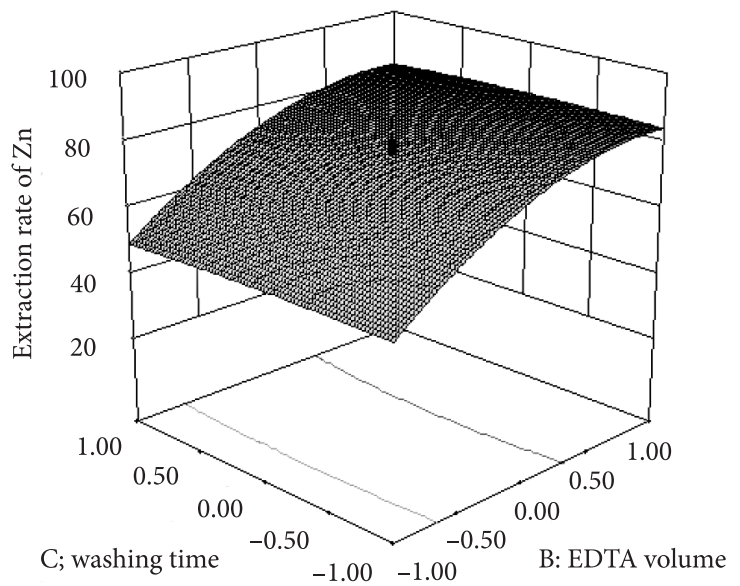

k)

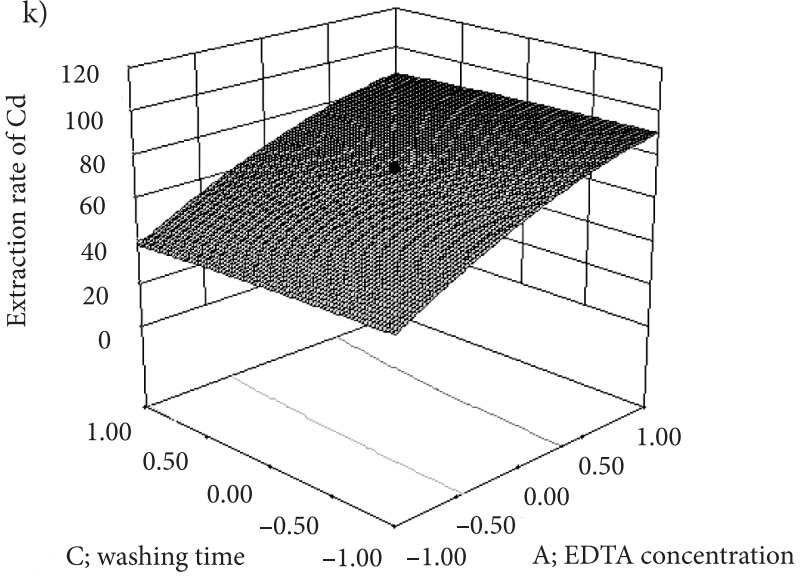

j)

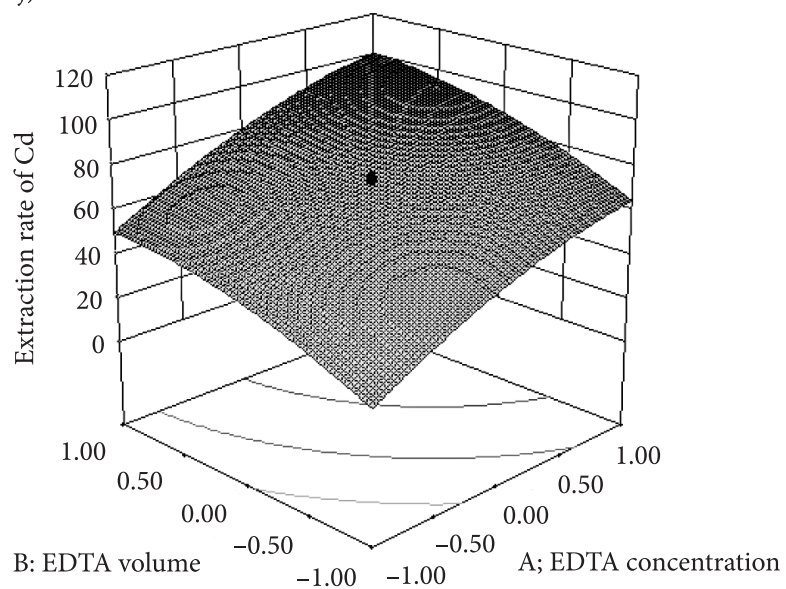

1)

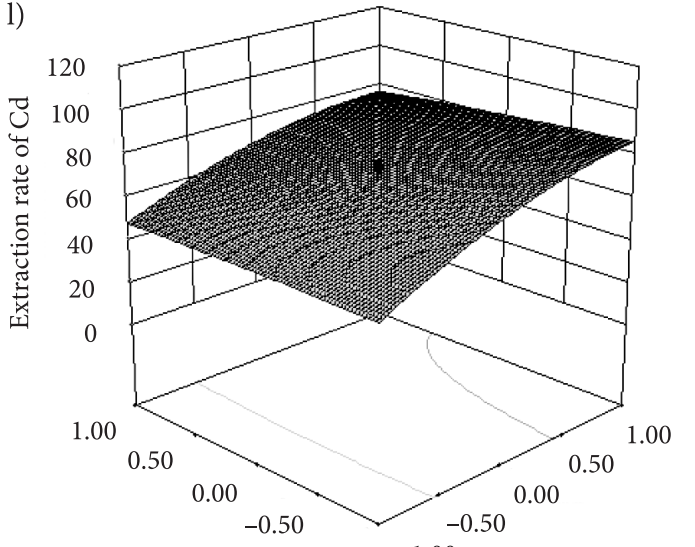

C; washing time $\quad-1.00 \quad-1.00 \quad$ B: EDTA volume

Figure 2. 3D surface showing the interaction effects of variables on extraction rates of various HMs: a) 3D surface of extraction rate of $\mathrm{Cu}$ and interaction of $\mathrm{AB} ; \mathrm{b}$ ) 3D surface of extraction rate of $\mathrm{Cu}$ and interaction of $\mathrm{AC} ; \mathrm{c}$ ) 3D surface of extraction rate of $\mathrm{Cu}$ and interaction of $\mathrm{BC} ; \mathrm{d}$ ) $3 \mathrm{D}$ surface of extraction rate of $\mathrm{Pb}$ and interaction of $\mathrm{AB}$; e) $3 \mathrm{D}$ surface of extraction rate of $\mathrm{Pb}$ and interaction of $\mathrm{AC}$; f) 3D surface of extraction rate of $\mathrm{Pb}$ and interaction of $\mathrm{BC} ; \mathrm{g}$ ) $3 \mathrm{D}$ surface of extraction rate of $\mathrm{Zn}$ and interaction of $\mathrm{AB}$;

h) 3D surface of extraction rate of $\mathrm{Zn}$ and interaction of $\mathrm{AC}$; i) 3D surface of extraction rate of $\mathrm{Zn}$ and interaction of $\mathrm{BC}$;

j) $3 \mathrm{D}$ surface of extraction rate of $\mathrm{Cd}$ and interaction of $\mathrm{AB}$; $\mathrm{k}$ ) $3 \mathrm{D}$ surface of extraction rate of $\mathrm{Cd}$ and interaction of $\mathrm{AC}$;

1) $3 \mathrm{D}$ surface of extraction rate of $\mathrm{Cd}$ and interaction of $\mathrm{BC}$

rate of $\mathrm{Cu}$ were EDTA concentration, solid-to-liquid ratio and oscillation time.

These facts are illustrated in Figure $2(\mathrm{a}-\mathrm{c})$. The tendencies of the extraction rates influenced by different factors are reflected by the curved surface. The interaction of factors are illustrated by the shape of the contour lines, an elliptical nature of the contour line indicated a significant interactions, while a circular contour line indicates the interaction between the corresponding variables is not significant (Francis et al., 2003; Yin, You, \& Jiang, 2011). As the 3D surface graph shows in Figure 2, the extraction rate of $\mathrm{Cu}$ increases obviously with the increase of EDTA volume and concentration, while the change with oscillating time is unapparent. There is a significant interaction between EDTA volume and concentration, while interactions between other factors are not significant.

(b) Regression model analysis of extraction rate of $\mathrm{Pb}$. The second-order polynomial regression equation showing the relationship between the $\mathrm{Pb}$ extraction rate $\left(Y_{2}\right)$ and three test variables is presented in Eq. (2):

$$
\begin{aligned}
& Y_{2}=-123.61689+48.09676 \times A+9.79840 \times \\
& B-2.83173 \times C-0.59945 \times A \times B+0.20523 \times \\
& A \times C-3.65177 E-0.04 \times B \times C-3.71889 \times \\
& A^{2}-0.15108 \times B^{2}+0.32478 \times C^{2},
\end{aligned}
$$

where $Y_{2}$ is the extraction rate of $\mathrm{Pb} ; A$ is the concentration of EDTA solution $\left(10^{-3} \mathrm{~mol} \cdot \mathrm{L}^{-1}\right) ; B$ is the solid-toliquid ratio; $C$ is the time of oscillation.

The ANOVA results for $Y_{2}$ were shown in Table 4. The ANOVA result of the regression model showed that the model is statistically extreme significant at the $95 \%$ confidence level $(P<0.001)$. There is no evidence of lack of fit. The coefficient of determination $\left(R^{2}\right)$ was calculated to be 0.96 , which means that the model could explains $96.33 \%$ of the values in the experiment, this result also proved a strong prediction of the model towards the response. 
Table 4. ANOVA for the reduced quadratic model (Eq. 2)

\begin{tabular}{|c|c|c|c|c|}
\hline Source & df & SS & MS & Prob $>$ F \\
\hline Model & 9 & 2371 & 59 & $<0.0001$ \\
\hline A & 1 & 10680 & 265 & $<0.0001$ \\
\hline B & 1 & 4779 & 119 & $<0.0001$ \\
\hline C & 1 & 7 & 0.17 & 0.6849 \\
\hline AB & 1 & 1149 & 29 & 0.0003 \\
\hline AC & 1 & 5 & 0.13 & 0.7220 \\
\hline BC & 1 & 0 & 0 & 0.9975 \\
\hline A2 & 1 & 2280 & 57 & $<0.0001$ \\
\hline B2 & 1 & 2352 & 58 & $<0.0001$ \\
\hline C2 & 1 & 17 & 0.43 & 0.5257 \\
\hline residual & 10 & 40 & & \\
\hline
\end{tabular}

For $Y_{2}$, two main factors $(A, B)$, one interaction term $(A B)$, and two second order factors $\left(A^{2}, B^{2}\right)$ were significant $(P<0.05)$. It indicated that the extraction rate of $\mathrm{Pb}$ was significantly influenced by EDTA concentration and solid-to-liquid ratio. The order of factors that affected the extraction rate of $\mathrm{Pb}$ were EDTA concentration, solid-toliquid ratio and oscillation time. These facts are illustrated in Figure $2(\mathrm{~d}-\mathrm{f})$, the extraction rate of $\mathrm{Pb}$ increases obviously with the increase of EDTA portion and concentration, while the change with oscillating time is unapparent. There is a significant interaction between solid-to-liquid ratio and EDTA concentration, while interactions between other factors are not significant.

(c) Regression model analysis of extraction rate of $\mathrm{Zn}$.

The second-order polynomial regression equation showing the relationship between the $\mathrm{Zn}$ extraction rate $\left(Y_{3}\right)$ and three test variables is presented in Eq. (3):

$$
\begin{aligned}
& Y_{3}=-71.39814+27.21643 \times A+7.75242 \times \\
& B-1.27599 \times C+2.86458 E-003 \times A \times B+ \\
& 0.21988 \times A \times C-7.47648 E-004 \times B \times C- \\
& 2.94314 \times A^{2}-0.14681 \times B^{2}+0.044762 \times C^{2},
\end{aligned}
$$

where $Y_{3}$ is the extraction rate of $\mathrm{Zn} ; A$ is the concentration of EDTA solution $\left(10^{-3} \mathrm{~mol} \cdot \mathrm{L}^{-1}\right) ; B$ is the ratio of solid-to-liquid; $C$ is the time of oscillation.

Table 5. ANOVA for the reduced quadratic model (Eq. 3)

\begin{tabular}{|c|c|c|c|c|}
\hline Source & df & SS & MS & Prob $>$ F \\
\hline Model & 9 & 1520 & 95 & $<0.0001$ \\
\hline A & 1 & 5507 & 343 & $<0.0001$ \\
\hline B & 1 & 4444 & 276 & $<0.0001$ \\
\hline C & 1 & 4 & 0.23 & 0.6408 \\
\hline AB & 1 & 0.03 & 0 & 0.9686 \\
\hline AC & 1 & 6 & 0.38 & 0.5489 \\
\hline BC & 1 & 0 & 0 & 0.9918 \\
\hline A2 & 1 & 1428 & 89 & $<0.0001$ \\
\hline B2 & 1 & 2221 & 138 & $<0.0001$ \\
\hline C2 & 1 & 0.33 & 0.02 & 0.8889 \\
\hline residual & 10 & 16 & & \\
\hline
\end{tabular}

The ANOVA results for $Y_{3}$ were shown in Table 5. Results showed the model was statistically highly significant at the 95\% confidence level $(P<0.001)$. There was no evidence of lack of fit. The coefficient of determination $\left(R^{2}\right)$ was calculated to be 0.9769 , which means that the model could explains $97.69 \%$ of the values in the experiment. The effect of $A, B, A^{2}$, and $B^{2}$ are extremely significant to the model in this case $(P<0.001)$. There is no interaction in any pair of factors. EDTA concentration and solid-to-liquid ratio were the main influence factors of $\mathrm{Zn}$ extraction rate. In contrast, the influence of the elution time was not significant. The order of factors that affected the extraction rate of Zn were EDTA concentration $(A)$, solid-to-liquid ratio $(B)$ and oscillation time $(C)$. These facts are illustrated in Figure 2 (g-i), the extraction rate of $\mathrm{Zn}$ increases obviously with the increase of EDTA portion and concentration, while the change with oscillating time is unapparent. The interactions between factors are not obviously.

(d) Regression model analysis of extraction rate of Cd.

The second-order polynomial regression equation showing the relationship between the Cd extraction rate $\left(Y_{4}\right)$ and three test variables is presented in Eq. (4):

$$
\begin{aligned}
& Y_{4}=-82.88057+22.58487 \times A+8.11971 \times \\
& B+3.80610 \times C+0.059669 \times A \times B+ \\
& 0.053288 \times A \times C-0.11628 \times B \times C- \\
& 1.89104 \times A^{2}-0.14648 \times B^{2}-0.34270 \times C^{2},
\end{aligned}
$$

where $Y_{4}$ is the extraction rate of $\mathrm{Cd} ; A$ is the concentration of EDTA solution $\left(10^{-3} \mathrm{~mol} \cdot \mathrm{L}^{-1}\right) ; B$ is the ratio of solid-toliquid; $C$ is the time of oscillation.

Table 6. ANOVA for the reduced quadratic model (Eq. (4))

\begin{tabular}{|c|c|c|c|c|}
\hline Source & df & SS & MS & Prob $>$ F \\
\hline Model & 9 & 1762 & 16 & $<0.0001$ \\
\hline A & 1 & 7995 & 76 & $<0.0001$ \\
\hline B & 1 & 4872 & 46 & $<0.0001$ \\
\hline C & 1 & 61 & 0.58 & 0.4651 \\
\hline AB & 1 & 11 & 0.11 & 0.7488 \\
\hline AC & 1 & 0.36 & 0 & 0.9543 \\
\hline BC & 1 & 43 & 0.41 & 0.5357 \\
\hline A2 & 1 & 590 & 6 & 0.0394 \\
\hline B2 & 1 & 2211 & 21 & 0.0010 \\
\hline C2 & 1 & 19 & 0.18 & 0.6769 \\
\hline residual & 10 & 105 & & \\
\hline
\end{tabular}

The ANOVA results for $Y_{4}$ were shown in Table 6 . Results showed the model was statistically extremely significant at the $95 \%$ confidence level $(P<0.001)$. There is no evidence of lack of fit. The coefficient of determination $\left(R^{2}\right)$ was calculated to be 0.8795 , which indicated a prediction of $87.95 \%$ of the experimental values. The effects of $A$ and $B$ are extremely significant $(P<0.001)$, and $B^{2}$ is significant to the model in this case $(P<0.05)$. There 
is no interaction in any pair of factors. The results indicated that EDTA concentration and solid-to-liquid ratio were the main influence factors of $\mathrm{Cd}$ extraction rate. In contrast, the influence of the elution time was not significant. The order of factors that affected the extraction rate of Cd were EDTA concentration $(A)$. Solid-to-liquid ratio $(B)$ and oscillation time $(C)$. These facts are illustrated in Figure $2(\mathrm{j}-\mathrm{l})$, the extraction rate of $\mathrm{Cd}$ increases obviously with the increase of EDTA portion and concentration, while the change with oscillating time is unapparent. The interactions between factors are not obvious.

The $3 \mathrm{D}$ response surface images are also in accordance with ANOVA results, which facilitate the overview of the interactions between two variables and their respectively impact for the extraction rate (Figure 2).

\subsection{Validation of the model}

Validation of the model was carried out by analysing experimental result under conditions predicted by the software. In this case, we set the extraction rate of $\mathrm{Cu}$

Table 7. Simulating data sheet by Design Expert

\begin{tabular}{|c|c|c|c|c|}
\hline Run & $\begin{array}{c}\text { EDTA } \\
\text { concentration } \\
/ 10^{-3} \mathrm{~mol} \cdot \mathrm{L}^{-1}\end{array}$ & $\begin{array}{c}\text { EDTA } \\
\text { volume } \\
/ \mathrm{mL}\end{array}$ & $\begin{array}{c}\text { Oscillating } \\
\text { time } \\
/ \mathrm{h}\end{array}$ & $\begin{array}{c}\text { Extraction } \\
\text { rate of } \\
\mathrm{Cu} / \%\end{array}$ \\
\hline 1 & 4.25 & 14.3 & 3.81 & 50 \\
\hline 2 & 2.08 & 26.2 & 5.89 & 50 \\
\hline 3 & 2.21 & 26.2 & 2.86 & 50 \\
\hline 4 & 2.00 & 29.1 & 4.55 & 50 \\
\hline 5 & 2.52 & 22.0 & 4.07 & 50 \\
\hline 6 & 2.00 & 28.2 & 5.24 & 50 \\
\hline 7 & 3.63 & 16.0 & 5.77 & 50 \\
\hline 8 & 2.44 & 23.2 & 2.97 & 50 \\
\hline 9 & 3.73 & 16.2 & 2.28 & 50 \\
\hline 10 & 2.38 & 24.0 & 2.76 & 50 \\
\hline 11 & 2.57 & 21.3 & 5.12 & 50 \\
\hline 12 & 2.27 & 24.5 & 3.72 & 50 \\
\hline 13 & 3.25 & 17.5 & 5.72 & 50 \\
\hline 14 & 3.11 & 18.3 & 3.68 & 50 \\
\hline 15 & 2.50 & 21.8 & 5.23 & 50 \\
\hline 16 & 2.02 & 27.9 & 4.69 & 50 \\
\hline 17 & 3.61 & 16.1 & 5.09 & 50 \\
\hline 18 & 2.18 & 24.8 & 5.42 & 50 \\
\hline 19 & 3.65 & 15.9 & 5.28 & 50 \\
\hline 20 & 2.00 & 28.5 & 4.92 & 50 \\
\hline 21 & 4.58 & 13.6 & 3.49 & 50 \\
\hline 22 & 3.39 & 17.3 & 2.65 & 50 \\
\hline 23 & 2.70 & 21.2 & 2.75 & 50 \\
\hline 24 & 2.21 & 26.2 & 2.89 & 50 \\
\hline 25 & 3.24 & 17.5 & 5.68 & 50 \\
\hline 26 & 4.35 & 14.0 & 5.61 & 50 \\
\hline 27 & 4.42 & 13.8 & 4.34 & 50 \\
\hline 28 & 3.69 & 16.0 & 3.38 & 50 \\
\hline 29 & 3.33 & 17.5 & 2.97 & 50 \\
\hline 30 & 2.53 & 21.6 & 5.43 & 50 \\
\hline
\end{tabular}

reaching to $50 \%$ as the objective of EDTA-enhanced soil washing, 30 runs of combinations were given by Design Expert, the predicted conditions run by the software are in Table 7. Through experimental validation of the runs of 15 and 20, the predicted and the actual (experimental) responses of the extraction rate of $\mathrm{Cu}(49.2 \%$ and $51.5 \%)$ were comparable, which inhibited a good correlation between the experimental and the predicted values, and hence, the model was successfully validated.

In practical application, single-factor experiment and optimization by RSM method could be used in fitting out the heavy metal removal model. The optimal combination of parameters could be obtained by setting appropriate objective. Additionally, practical conditions such as relationship between EDTA concentration and solid-to-liquid ratio should be given overall consideration to reach a best balance between cost and efficiency under the premise of achieve repair purpose.

\section{Conclusions}

This work illustrates the feasibility of EDTA-enhance soil washing for multiple HMs contamination in the soil. Moreover, CCD and regression analysis method were proofed to be practicable and valid in determining the optimized combinations of soil washing conditions whilst maintaining economical technical parameters with high extraction rate. This approach is competitive in treating soil contamination with other types of pollutants for evaluating technical parameters fast and effectively, and of lowest cost.

\section{Acknowledgments}

The authors would like to thank the anonymous reviewers for their comments and suggestions that helped in improving the manuscript.

\section{Funding}

This study was supported by the National Key R\&D Program of China (No. 2017YFC0210504).

\section{Disclosure statement}

None of the authors has competing financial, professional, or personal interests from other parties.

\section{References}

Arao, T., Ishikawa, S., Murakami, M., Abe, K., Maejima, Y., \& Makino, T. (2010). Heavy metal contamination of agricultural soil and countermeasures in japan. Paddy Water Environs, 8(3), 247-257. https://doi.org/10.1007/s10333-010-0205-7

Barker, T. B. (1985). Quality by experimental design. New York: Marcel Dekker.

Cameselle, C., \& Alberto, P. (2016). Enhanced electromigration and electro-osmosis for the remediation of an agricultural soil 
contaminated with multiple heavy metals. Process Safety \& Environmental Protection, 104, 209-217.

https://doi.org/10.1016/j.psep.2016.09.002

Ciccu, R., Ghiani, M., Serci, A., Fadda, S., Peretti, R., \& Zucca, A. (2003). Heavy metal immobilization in the mining-contaminated soils using various industrial wastes. Minerals Engineering, 16(3), 187-192.

https://doi.org/10.1016/S0892-6875(03)00003-7

Dean, A., \& Voss, D. (2010). Design and analysis of experiments. Beijing: World Publishing Corporation.

Dermont, G., Bergeron, M., Mercier, G., \& Richerlaflèche, M. (2008). Soil washing for metal removal: a review of physical/ chemical technologies and field applications. Journal of Hazardous Materials, 152(1), 1-31.

https://doi.org/10.1016/j.jhazmat.2007.10.043

Di Palma, L., Ferrantelli, P., \& Medici, F. (2005). Heavy metals extraction from contaminated soil: recovery of the flushing solution. Journal of Environmental Management, 77(3), 205211. https://doi.org/10.1016/j.jenvman.2005.02.018

Elnaggar, N. E. A., Elshweihy, N. M., \& Elewasy, S. M. (2016). Identification and statistical optimization of fermentation conditions for a newly isolated extracellular cholesterol oxidase-producing streptomyces cavourensis strain neae- 42 . BMC Microbiology, 16(1), 217.

https://doi.org/10.1186/s12866-016-0830-4

Evangelou, M. W., Bauer, U., Ebel, M., \& Schaeffer, A. (2007). The influence of edds and edta on the uptake of heavy metals of cd and cu from soil with tobacco nicotiana tabacum. Chemosphere, 68(2), 345-353. https://doi.org/10.1016/j.chemosphere.2006.12.058

Ferraro, A., Fabbricino, M., Hullebusch, E. D. V., Esposito, G., \& Pirozzi, F. (2016). Effect of soil/contamination characteristics and process operational conditions on aminopolycarboxylates enhanced soil washing for heavy metals removal: a review. Reviews in Environmental Science \& Bio/technology, 15(1), 111-145. https://doi.org/10.1007/s11157-015-9378-2

Finzgar, N., Jez, E., Voglar, D., \& Lestan, D. (2014). Spatial distribution of metal contamination before and after remediation in the Meza Valley, Slovenia. Geoderma, 217-218, 135-143. https://doi.org/10.1016/j.geoderma.2013.11.011

Francis, F., Sabu, A., Nampoothiri, K. M., Ramachandran, S., Ghosh, S., Szakacs, G., \& Pandey, A. (2003). Use of response surface methodology for optimizing process parameters for the production of $a$-amylase by aspergillus oryzae. Biochemical Engineering Journal, 15(2), 107-115.

https://doi.org/10.1016/S1369-703X(02)00192-4

Gangadharan, D., Sivaramakrishnan, S., Nampoothiri, K. M., Sukumaran, R. K., \& Pandey, A. (2008). Response surface methodology for the optimization of alpha amylase production by bacillus amyloliquefaciens. Bioresour Technology, 99(11), 4597-4602.

https://doi.org/10.1016/j.biortech.2007.07.028

Gao, Y., He, J., Ling, W., Hu, H., \& Liu, F. (2003). Effects of organic acids on copper and cadmium desorption from contaminated soils. Environment International, 29(5), 613-618. https://doi.org/10.1016/S0160-4120(03)00048-5

GB 9834-88:1988. Method for determination of soil organic matter. Ministry of Agriculture of the People's Republic of China.

Guo, X., Wei, Z., Wu, Q., Li, C., Qian, T., \& Zheng, W. (2016). Effect of soil washing with only chelators or combining with ferric chloride on soil heavy metal removal and phytoavailability: Field experiments. Chemosphere, 147, 412-419. https://doi.org/10.1016/j.chemosphere.2015.12.087
Gupta, B., Poudel, B. K., Pathak, S., Tak, J. W., Lee, H. H., Jeong, J. H., Choi, H. G., Yong, C. S., \& Kim, J. O. (2016). Effects of formulation variables on the particle size and drug encapsulation of imatinib-loaded solid lipid nanoparticles. Aaps Pharmscitech, 17(3), 652-662. https://doi.org/10.1208/s12249-015-0384-z

Haapea, P., \& Tuhkanen, T. (2006). Integrated treatment of PAH contaminated soil by soil washing, ozonation and biological treatment. Journal of Hazardous Materials, 136(2), 244-250. https://doi.org/10.1016/j.jhazmat.2005.12.033

Hwang, C. F., Chang, J. H., Houng, J. Y., Tsai, C. C., Lin, C. K., \& Tsen, H. Y. (2012). Optimization of medium composition for improving biomass production of Lactobacillus plantarum, Pi06 using the Taguchi array design and the Box-Behnken method. Biotechnology \& Bioprocess Engineering, 17(4), 827834. https://doi.org/10.1007/s12257-012-0007-4

Kang, C. H., \& So, J. S. (2016). Heavy metal and antibiotic resistance of ureolytic bacteria and their immobilization of heavy metals. Ecological Engineering, 97, 304-312. https://doi.org/10.1016/j.ecoleng.2016.10.016

Khosravi, K. D., Vasheghani, F. E., Shojaosadati, S. A., \& Yamini, Y. (2004). Effect of process variables on supercritical fluid disruption of Ralstonia eutropha cells for Poly(R-hydroxybutyrate) recovery. Biotechnology Progress, 20, 1757-1765. https://doi.org/10.1021/bp0498037

Kulikowska, D., Gusiatin, Z. M., Bułkowska, K., \& Kierklo, K. (2015). Humic substances from sewage sludge compost as washing agent effectively remove $\mathrm{Cu}$ and $\mathrm{Cd}$ from soil. Chemosphere, 136, 42-49. https://doi.org/10.1016/j.chemosphere.2015.03.083

Leštan, D., Luo, C. L., \& Li, X. D. (2008). The use of chelating agents in the remediation of metal-contaminated soils: A review. Environmental Pollution, 153(1), 3-13. https://doi.org/10.1016/j.envpol.2007.11.015

Lionberger, R. A., Lee, S. L., Lee, L., Raw, A., \& Yu, L. X. (2008). Quality by design: concepts for andas. AAPS Journal, 10(2), 268-276.

https://doi.org/10.1208/s12248-008-9026-7

Lo, I. M. C., Tanboonchuy, V., Yan, D. Y. S., Grisdanurak, N., \& Liao, C. H. (2012). A hybrid approach for Pahs and metals removal from field-contaminated sediment using activated persulfate oxidation coupled with chemical-enhanced washing. Water Air \& Soil Pollution, 223(8), 4801-4811. https://doi.org/10.1007/s11270-012-1236-Z

Madeira, C., Ribeiro, S. C., Turk, M. Z., \& Cabral, J. M. (2010). Optimization of gene delivery to HEK293T cells by microporation using a central composite design methodology. Biotechnology Letters, 32(10), 1393-1399.

https://doi.org/10.1007/s10529-010-0327-4

Mandal, A., Purakayastha, T. J., \& Patra, A. K. (2014). Phytoremediation of arsenic contaminated soil by Chinese brake fern (Pteris vittata): Effect on soil microbiological activities. Biology \& Fertility of Soils, 50, 1247-1252.

https://doi.org/10.1007/s00374-014-0941-8

Mao, X., Jiang, R., Xiao, W., \& Yu, J. (2015). Use of surfactants for the remediation of contaminated soils: a review. Journal of Hazardous Materials, 285, 419-435.

https://doi.org/10.1016/j.jhazmat.2014.12.009

Moradpour, Z., Ghasemian, A., Mohkam, M., \& Ghasemi, Y. (2012). Isolation, molecular identification and statistical optimization of culture condition for a new extracellular cholesterol oxidase-producing strain using response surface methodology. Annals of Microbiology, 63(3), 941-950.

https://doi.org/10.1007/s13213-012-0547-z 
Moutsatsou, A., Gregou, M., Matsas, D., \& Protonotarios, V. (2016). Washing as a remediation technology applicable in soils heavily polluted by mining-metallurgical activities. Chemosphere, 63(10), 1632-1640.

https://doi.org/10.1016/j.chemosphere.2005.10.015

Mulligan, C. N., Yong, R. N., \& Gibbs, B. F. (2001). Remediation technologies for metal-contaminated soils and groundwater: an evaluation. Engineering Geology, 60, 193-207. https://doi.org/10.1016/S0013-7952(00)00101-0

Peters, R. W. (1999). Chelant extraction of heavy metals from contaminated soils. Journal of Hazardous Materials, 66(1-2), 151-210. https://doi.org/10.1016/S0304-3894(99)00010-2

Poudel, B. K., Marasini, N., Tran, T. H., Choi, H. G., Yong, C. S., \& Kim, J. O. (2012). Formulation, characterization and optimization of valsartan self-microemulsifying drug delivery system using statistical design of experiment. Chemical \& Pharmaceutical Bulletin, 60(11), 1409-1418. https://doi.org/10.1248/cpb.c12-00502

Shen, N., Wang, Q., Qin, Y., Zhu, J., Zhu, Q., Mi, H., Wei, H., \& Huang, R. (2014). Optimization of succinic acid production from cane molasses by Actinobacillus succinogenes GXAS137 using response surface methodology (RSM). Food Science \& Biotechnology, 23(6), 1911-1919. https://doi.org/10.1007/s10068-014-0261-7

Sugashini, S., \& Begum, K. M. M. S. (2013). Optimization using central composite design (CCD) for the biosorption of $\mathrm{Cr}(\mathrm{VI})$ ions by cross linked chitosan carbonized rice husk (CCACR). Clean Technologies \& Environmental Policy, 15(2), 293-302. https://doi.org/10.1007/s10098-012-0512-3

Sun, B., Zhao, F. J., \& Lombi, E. (2001). Leaching of heavy metals from contaminated soils using EDTA. Environmental Pollution, 113(2), 111-120. https://doi.org/10.1016/S0269-7491(00)00176-7
Tanyildizi, M. S. (2011). Modeling of adsorption isotherms and kinetics of reactive dye from aqueous solution by peanut hull. Chemical Engineering Journal, 168, 1234-1240. https://doi.org/10.1016/j.cej.2011.02.021

Tsang, D. C., \& Lo, I. M. 2006. Competitive cu and cd sorption and transport in soils: a combined batch kinetics, column, and sequential extraction study. Environmental Science \& Technology, 40(21), 6655-6661. https://doi.org/10.1021/es060625i

Voglar, D., \& Lestan, D. (2012). Pilot-scale washing of metal contaminated garden soil using EDTA. Journal of Hazardous Materials, 215-216, 32-39. https://doi.org/10.1016/j.jhazmat.2012.02.022

Wasay, S. A., Barrington, S., \& Tokunaga, S. (2001). Organic acids for the in-situ remediation of soils polluted by heavy metals: soil flushing in columns. Water, Air, \& Soil Pollution, 127(1), 301-314. https://doi.org/10.1023/A:1005251915165

Wuana, R. A., Okieimen, F. E., \& Imborvungu, J. A. (2010). Removal of heavy metals from a contaminated soil using organic chelating acids. International Journal of Environmental Science \& Technology, 7, 485-496. https://doi.org/10.1007/BF03326158

Xia, W. B., Gao, H., Wang, X. H., Zhou, C. H., Liu, Y. G., Fan, T., \& Wang, X. (2009). Application of EDTA decontamination on soils affected by mining activities and impact of treatment on the geochemical partition of metal contaminants. Journal of Hazardous Materials, 164(2-3), 936-940. https://doi.org/10.1016/j.jhazmat.2008.08.092

Yin, X. L., You, Q. H., \& Jiang, Z. H. (2011). Optimization of enzyme assisted extraction of polysaccharides from Tricholoma matsutake by response surface methodology. Carbohydrate Polymers, 86(3), 1358-1364. https://doi.org/10.1016/j.carbpol.2011.06.053 